\title{
Sciendo
}

\section{Integration Perspectives of Eurasian Land-Based Transport Corridors: Empirical Evidence from the OBOR and Rail Baltica Initiatives}

\author{
Anatoli Beifert \\ Wismar University of Applied Sciences \\ Wismar Business School \\ Philipp-Müller-Str. 14 \\ Wismar 23966, Germany \\ Email: anatoli.beifert@hs-wismar.de
}

Gunnar Prause

Department of Business Administration

School of Business and Governance

Tallinn University of Technology

Ehitajate tee 5

Tallinn 19086, Estonia

Email: gunnar.prause@taltech.ee

Yury Shcherbanin

Institute of Economic Forecasting (IEF)

Russian Academy of Sciences

Nahimovskii prospekt 47

Moscow 117418, Russia

Email: shcherbaninya@mail.ru

\begin{abstract}
Land-based Trans-Eurasian transport corridors, their current development and perspectives have been high on the political agenda in the last two decades not only in Europe and China but also in the transit countries such as Russia, Belarus and Kazakhstan. A number of conceptual initiatives are already being implemented. The Belt and Road or the One Belt, One Road (OBOR) initiative on the Chinese side and the Rail Baltica project from the European perspective have gained special attention. Big-scale infrastructural projects are also being implemented by transit countries, e.g., the construction of a motorway from China to Europe-from Kazakhstan via Russia to Belarus-to facilitate
\end{abstract}


the land-based shortcut for cargo transport within the Eurasian transport corridor. This article investigates the general framework conditions of infrastructural investments into projects related to Eurasian logistics and discusses strategic areas of intersection between the European activities and the New Silk Way. In the framework of the OBOR initiative, this article also addresses the interaction of the Chinese-Kazakh-Russian-Belarusian-Polish railway transport, with a special focus on Belarusian-Polish crossborder issues. The authors have participated in several projects focusing on transport corridors and discuss the research question of how different Eurasian land-based transport corridors can be integrated and which strategic role can the Rail Baltica project play in the context of the New Silk Route. The research is based on surveys, expert interviews, secondary data research and case studies.

Keywords: Eurasian land bridge, New Silk Road, Rail Baltica, transport corridors

\section{Introduction}

Transport and logistics development is considered as one of the most important growth criteria today. However, the construction and enlargement of logistics infrastructure is very costly and requires large-scale investments, which is why an in-depth analysis and a wider understanding of this issue is of high importance. Transit logistics shall be viewed as a complex mechanism considering not only economic variables but also a wide range of risks and factors, such as environmental issues, politically loaded domestic risks in transit countries, political risks imposed externally (e.g., US sanctions against Russia involving gas pipelines, road and rail transit through Ukraine, EU sanctions against Russian ports in Crimea), technical preconditions of hardbased infrastructure (e.g., differences of the maximum allowed train's length in the EU Member States and in Russia or Belarus), etc.

The analysis published by the EU Commission in February 2019 shows that political and economic factors have the greatest impact on cargo/container transport within the Trans-Eurasian transport corridor (Pieriegud, 2019). However, despite the abovementioned problems, during the last decades, the socio-economic cooperation and bilateral investment climate in terms of 
Eurasian land-based transport corridors (TC) between the European Union and China have been significantly intensified. Important initiatives such as the Rail Baltica project and One Belt, One Road (OBOR) are trying to overcome shortcomings in the Eurasian land bridge and attract investments mostly focusing on infrastructure development projects in Europe, China, as well as in transit countries such as Kazakhstan, Russia and Belarus (Beifert, Shcherbanin \& Vinokurov, 2018). Furthermore, due to the fact that the OBOR countries will host most of the world's new infrastructure-related investments in the coming decades, it is also highly important that these projects comply with current environmental regulations and requirements (Beifert, Shcherbanin \& Vinokurov, 2018). Therefore, future and current investors, as well as users of OBOR or Rail Baltica related projects, shall pay attention to environmental issues. Consequently, common actions aiming to drive green investments in the Belt and Road should lead the way for greening OBOR projects as well as inspire future investors and stakeholders to green initiatives.

In a number of White Papers on transport, the European Commission outlined a political framework for the EU transport policy highlighting a common goal to shift significant cargo volumes away from the dominant road traffic towards greener transport modes. Special attention is paid to supporting measures for the environmentally friendly transport sector with safer and efficient transportation by reducing accidents, congestions and negative impacts through emissions (White Papers COM(2001) 370 final \& $\operatorname{COM}(2011) 0144$ final). The concept of green transport corridors (GTC) was introduced in 2006 as an initiative of the European Commission in the Freight Transport Logistics Action Plan as the necessity for the sustainable and environmentally friendly transport sector, providing safer and efficient transportation by reducing accidents, congestions and negative impacts through emissions like noise, light and pollution (BSR Transport, 2012; Prause \& Hunke, 2014). The concept of GTC comprises an integrated transport concept, whereas sea shipping, rail, inland waterways and road transport modes complement each other in an efficient and environmentally friendly way (Prause \& Hunke, 2014; Lee, 2005; Hunke \& Prause, 2013).

The GTC concept contributes to the attainment of the European 2050 targets by becoming more independent of fossil fuel and by cutting carbon emissions in transport by $60 \%$ until 2050 . The GTC strives for establishing multimodal trans-shipment routes with a concentration of freight traffic between major hubs and by relatively long distances of transport, now being marked by reduced environmental and climate impact while increasing safety and 
efficiency with the application of sustainable logistics solutions (Hunke \& Prause, 2013; Schröder \& Prause, 2015). In some EU-funded projects on territorial cooperation, the GTC concept is being implemented in the Rail Baltica Growth Corridor and the East-West Transport Corridor. Since the ideas of the GTC concept comprise interdependency between the traditional supply chain management and environmental issues, and also performance management control systems are being utilized in European transport corridors such as Rail Baltica (Lee, 2015; Sarkis, 2001), these experiences might be transferred, integrated into and utilized by the OBOR projects.

Finally, the progress in new information technologies, comprising the internet of things (IoT), Industry 4.0, blockchain technology and smart contracts, enables new forms of communication and cooperation along the transport corridors by offering new possibilities for enhanced efficiency, for sustainable entrepreneurial growth as well as for the implementation of greener transportation (Philipp et al., 2019; Prause \& Hoffmann, 2017; Prause, 2014a; 2014b). Hence, the investigation of OBOR projects has also come to include the consideration of growth perspectives in the context of logistics service clusters and other business activities together with facilitating new information technologies (Prause, 2014a; 2014b; Sheffi, 2012)

\section{Eurasian investment perspectives in OBOR projects}

The development of the OBOR initiative highly depends on investors' readiness and willingness to participate in infrastructural projects along the land-based Eurasian transport corridor (TC) (Beifert, Shcherbanin \& Vinokurov, 2018). Although officially started in 2009, the Eurasian landbased part of the OBOR initiative, due to the lack of the critical mass of needed infrastructural investments, especially in such transit countries like Russia, has served rather as a transit route into the heart of Eurasia than an efficient link between China and Western Europe.

According to the newest press reports (June-July 2019) all necessary preparations to fill a missing link along the OBOR TC (here: a road-based highway from the Russian border with Kazakhstan to the Russian border with Belarus) are said to be completed. This project has already been named "the construction of the century". Once finished, this transport corridor shall take one of the leading roles within OBOR, beginning at the Chinese port 
of Lianyungang on the Yellow Sea, stretching along China's longest road, the Lianhuo Expressway, moving through Kazakhstan's dry port Khorgos Gateway and finally going through Russia and Belarus to Western Europe. This TC aims at the development of a practical multimodal ecosystem, combining road, rail and air transport modes and hubs and even change the current shipment map of goods between Europe and China. According to plans, this highway might allow road-based container transport to move between Europe and China in 11 days, compared to $24-36$ days by sea, and 12-20 days by rail (Beifert, Shcherbanin \& Vinokurov, 2018).

\section{Figure 1. Estimation of container shipment from China to Western Europe}

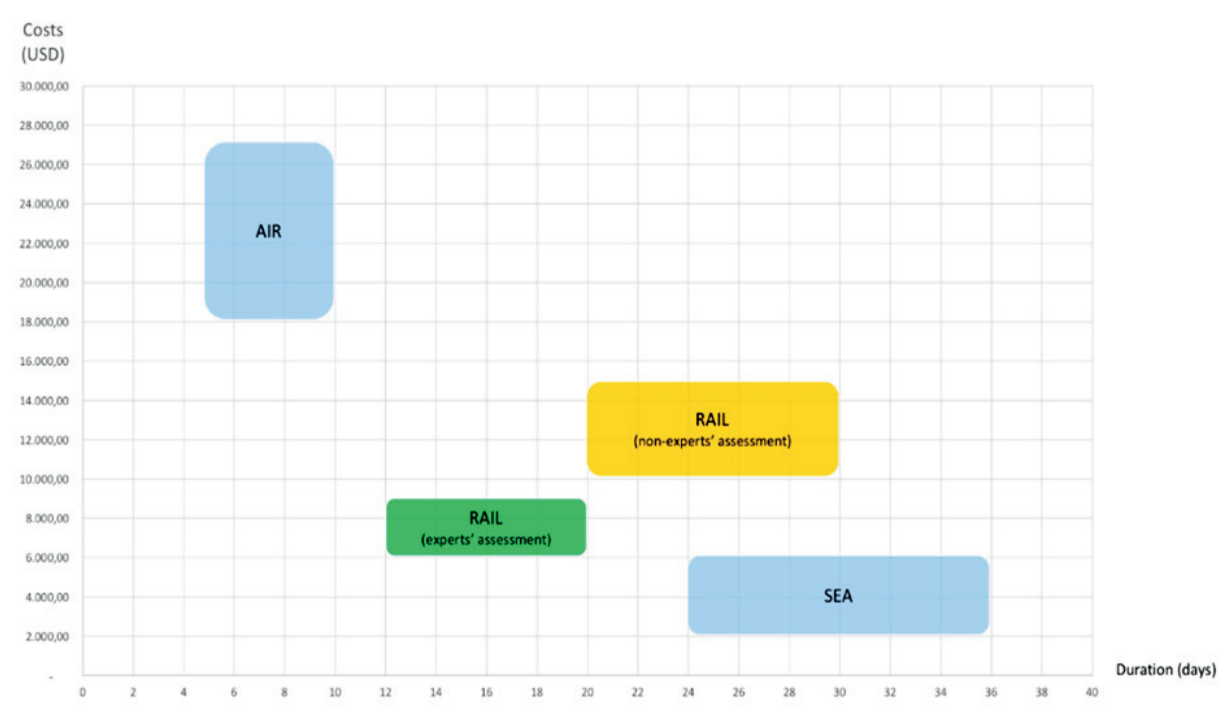

Source: Beifert, Shcherbanin \& Vinokurov, 2018

The above figure shows the current time-costs estimation of different modes of transport (here: air, sea and rail) for a standard TEU container from China to Western Europe made within IIASA study on Eurasian transport corridors in 2018 (Beifert, Shcherbanin \& Vinokurov, 2018). The responders were divided into 'expert or active users' of OBOR such as integrators, rail terminals operators, logistics service providers and 'nonexpert or passive users' such as, e.g., seaports operators, consignors, etc. The results demonstrated that non-involved potential stakeholders evaluate the capacity of OBOR overland transit route as cost-intensive and relatively slow, thus according to non-experts' evaluation, the rail mode shall not be considered as an object for potential investments at all. Due to the fact that 
there is almost no road-based link within OBOR, it is of high importance to increase awareness about the TC's potential in order to attract and improve the investment climate. Investments in the framework of this new EuropeChina highway are said to be $c a$. 8-9 billion euros, whereas most of the financing shall come from private investors with a financial "backup" from the Russian government, which is said to amount to $c a$. 500 million euros. According to main investor's statements, this highway is being developed mainly for cargo transport with a road toll as a main source of revenue. Estimated payback time is $12-14$ years.

Along with this, other EU funded projects are underway in other transit countries. For example, two new contracts were signed in July 2019 by the European Investment Bank (EIB) and the government of Belarus. European investors and the EIB support transport services and infrastructural projects in Belarus by lending commitment, supporting national financial institutions and improving connectivity and the attractiveness of Belarus as a transit country in the total of 335 million euros. In 2019, the EIB also signed agreements aiming at supporting the water sector and projects implemented by logistics-related small and medium enterprises. However, despite these newest developments described above, it might be stated that the investment climate along the OBOR initiative is rather low. A survey of 30 European companies, representing exporters, the transport and the logistics sector, has been conducted in the framework of the study. Among other things, it showed that among the main risk factors for potential investors from Europe in the OBOR transport corridor are the different non-tariff barriers in China and cumbersome regulations, which may prove extra challenging for the European companies considering the utilization of Europe-China transport corridors. In spite of the fact that European companies have frequently mentioned such factors, including the low quality of logistics services, longdrawn-out customs procedures, inspections, official procedures of border clearance of transported cargo, as well as rather poor logistics infrastructure in the transit countries, all those criteria appeared to be insignificant. On the other hand, it was noted that a potential will of European investors considerably depends on "soft factors" such as the level of sustainability and transparency in decisions regarding future investments, rather than on pure economic indicators, e.g., payback or profitability. While risk perception in the long perspective increases and, correspondingly, the readiness to invest decreases in China and the transit countries (here: mainly Russia, Kazakhstan and Belarus) compared to the European countries, a negative dynamics demonstrated a disproportionate decrease. Hence, a high level 
of political uncertainty and economic stability in China, and in the transit countries, has been named as the main factors. Further options to increase the attractiveness of OBOR for European investors mentioned was also motivating Chinese companies for direct investments in infrastructural projects instead of just lending finances or subsidies to the European partners. The so-called sharing of direct investments and commercial risks may improve the investment attractiveness for European stakeholders, and it might be seen as a positive indicator of a favorable and sustainable investment climate.

Linear regression analysis showed that Europe's willingness to invest depends mainly on the quality of institutions in China and in Europe, while such issues as customs services and the quality of transport infrastructure matter as well. Furthermore, it was stated that the investment climate of European companies to contribute to the European part of the OBOR infrastructure depends mainly on the quality of institutions in China, e.g., decisions regarding making investments in the Lithuanian or Polish infrastructure may be positive if the sustainability of Chinese institutions and regulations is secured. On the other hand, the readiness to invest in Chinese projects is highly related to the quality of Chinese infrastructure, i.e., although potential European investors are not ready to invest in the Chinese infrastructure projects from scratch, in the case of already ongoing projects, the European investors positively consider sharing the commercial and political risks.

The investment climate of stakeholders from the transit countries into OBOR projects mainly depend on government regulations in the transit countries, i.e., the investors' readiness increases if the sustainability of governmental regulations and their transparency in the transit countries remains stable and predictable. To be noted that both of the abovementioned factors are not infrastructural, but of so-called "soft" nature. Potential investors tend to overestimate the risks unless the dynamics of institutions and government regulation development in China or in the transit countries remains stable. This fact keeps potential investors from actively participating in OBOR projects until the risks are predictable and relevant policy regulations are transparent or sustainable. In addition to that, expert interviews that were executed in recent times by the authors in Russia revealed that the current situation of COVID-19 has had a negative effect both on transported volumes as well as on the investment climate. Thus, the impact of the ongoing pandemic represents an important factor for the investment climate of the OBOR projects with a negative consideration. 
Further qualitative data analysis of the investment climate in terms of transportation corridors' development along the OBOR corridor in Europe, China and the transit countries demonstrated that the willingness to invest into infrastructural projects in China, Europe or the transit countries as a part of transportation corridors is mainly related to the quality of national logistics infrastructure, the quality of institutions and logistic-related costs. However, these factors were considered differently for different countries, e.g., national logistics infrastructure and the quality of institutions were significant for China. Logistics-related costs were important factors for the transit countries and such aspects as 'green logistics' or sustainability issues were significant for the European investors.

Gained results also revealed that European investors still perceive the challenges and risks in the transit countries as being much higher than in Europe or even in China. Criteria such as unsustainable transportation tariffs and tariff policies were named as significant challenges for China and the transit countries. Additionally, the following measures were named as important issues that might increase the investment attractiveness of OBOR-related projects in the future:

a) Integration initiatives of hard components (e.g., rail gauges, terminals, maximum allowed length of cargo trains, etc.) and soft components (i.e., regulations, transport tariff system) in Europe, China and also the transit countries;

b) International coordination of land-based transport corridors, including the coordination of investment policies;

c) Development of new business models and integrative utilization of available train capacity of different integrators, e.g., implementation of integrative joint projects such as XL-train or enlargement of the length of cargo trains, efficient utilization through fitting platforms in cargo trains, etc.;

d) Sustainable and transparent tariff system, e.g., a transparent tariff system/formula for basic rail services for a period of at least three years;

e) Increasing awareness among potential stakeholders from China and the transit countries of the green transport corridor concept;

(f) Raising awareness among potential investors in Eurasian land-based transit projects, the OBOR initiative in general as well as real current capabilities of the EU-China land-based (here: mainly rail) transit routes and options.

An important issue that is currently often hidden in infrastructural and technical discussions is the related economic growth potential along the 
OBOR corridors. Transport corridors offer the opportunity of entrepreneurial growth in the form of logistics service clusters but also for complementing business activities (Prause \& Hunke, 2014; Prause, 2014a; 2014b; Sheffi, 2012). These growth potentials have already been a study point in EUfunded GTC projects, and they may be applied in a form analogous to the OBOR corridors. New technical developments such as the IoT, Industry 4.0, the blockchain technology and smart contracts further spur the growth processes since communication and cooperation intensity and quality within supply chains represent strategic factors that enhance supply chain efficiency and that are facilitating transparency and trust, which fuel entrepreneurial activities and cooperation (Philipp et al., 2019; Prause, 2014a; 2014b; Prause et al., 2013). New research results point out that especially the use of blockchain and smart contract technologies help foster entrepreneurial cooperation, streamline supply chain processes, reduce transaction costs and handle legal processes (Philipp et al., 2019). Thus, the use of these new technologies in the frame of the OBOR activities bears a huge potential for improvement.

\section{The challenges of Eurasian land-based transport corridors}

A general consideration of transport modes shows that maritime transport definitely dominates in the Europe-China trade, accounting around 98\% of all cargo transported between China and Europe; air transport contributes to approx. 1.5-2\%, and railway transport 0.5-1\% (Pieriegud, 2019; Beifert, Shcherbanin \& Vinokurov, 2018). Approximately 80\% of Europe-China trade is carried in containers, ca. $90 \%$ of European imports from China and $70-75 \%$ of European exports to China. At the same time, over the last four years, cargo flows from China to Europe by rail through the EAEU have doubled every year (although from a low base). In 2018, the volume of transported cargo from China to EU by rail amounted to 816 thousand tons (ca. $1.4 \%$ of the total transported volume), with the total value of 8.9 billion euros (2.5\% of the total exports of China to EU); and ca. 562 thousand tons (ca. 1\% of the total transported volume) from the EU to China, which values to $c a .6$ billion euros or $3.2 \%$ of the total traded value. From the perspective of the transit countries as well as on the EU side, Chinese subsidies are seen not only in positive terms but also as a systemic risk to the trans-Eurasian container cargo flow. For example, a number of 
central Chinese provinces subsidize exports to the average sum of 2,500 US dollars per 40-feet container (FEU) that may account approximately $0.3-0.4 \%$ of the export costs (Beifert, Shcherbanin \& Vinokurov, 2018). On the other hand, it should be mentioned that these subsidies on the Chinese side have positively influenced the transit volumes of cargo flows within the Trans-Eurasian transport corridor. To attract additional cargo flows in all countries along the China-EAEU-EU axis, both coordinated investment policies and the removal of trade barriers should be implemented. Based on the analysis of trade flows and tariff structure, further growth in EUChina railway cargo turnover through the EAEU countries may be clearly forecasted (Pieriegud, 2019; Beifert, Shcherbanin \& Vinokurov, 2018). For the transit countries, a key advantage of continental cooperation within the OBOR area is the promise of increased transport capacity that might generate a number of positive effects for economic development. Utilization of transport networks in a more efficient manner may lead to better internal connectivity between inner-Eurasian regions, i.e., Central Asia, Siberia, the Urals, and the Caucasus). It is particularly important for the transit countries to promote the development of transport infrastructure, especially in landlocked countries.

Figure 2. The main $O B O R$ routes

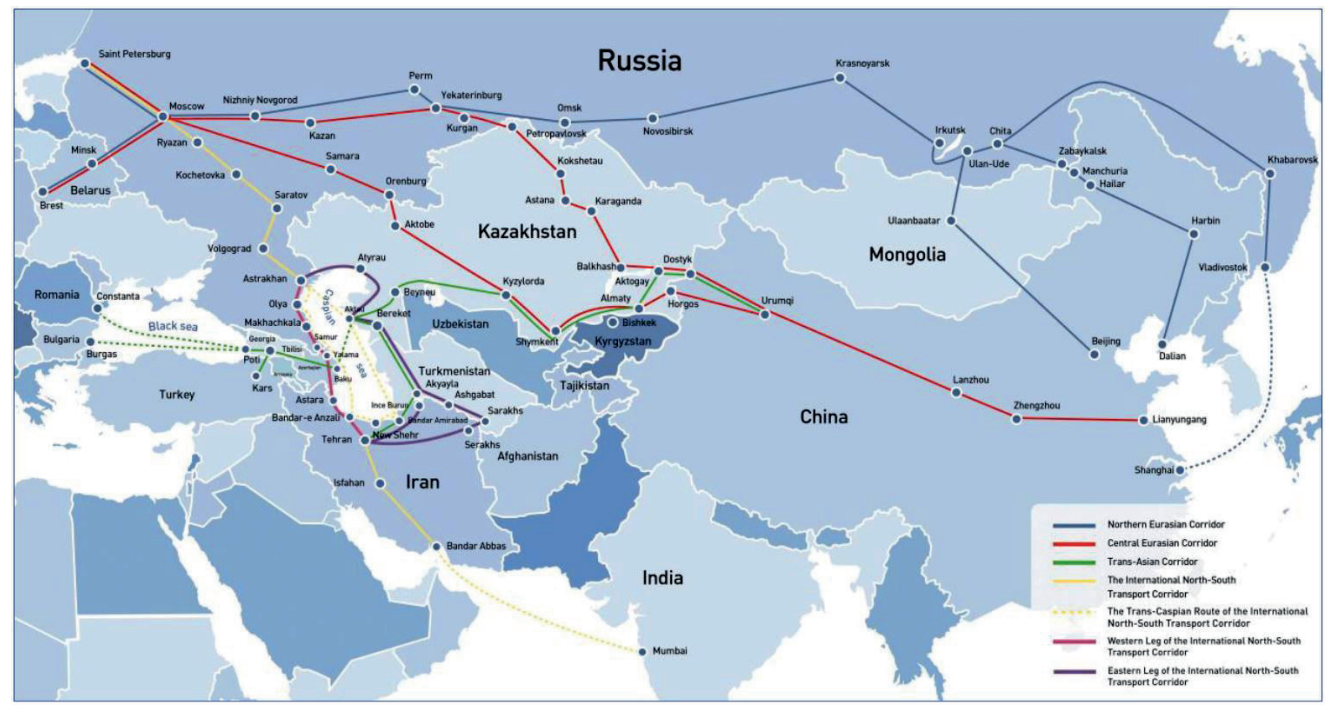

Source: Beifert, Shcherbanin \& Vinokurov, 2018 
As indicated in the figure, the main land-based OBOR routes are the following:

- Northern Eurasian corridor, i.e., China-Russia-Europe via the Far East and Eastern Siberia in Russian Federation, including the First Transport Belt: Tyumen-Omsk-Novosibirsk-KrasnoyarskIrkutsk; and the Second Transport Belt: Irkutsk-Chita-KhabarovskVladivostok.

- Central Eurasian corridor, i.e., China-Kazakhstan-Russia-Europe, through Kazakhstan and the Russian Federation

- Trans-Asian corridors, i.e., utilizing transport corridors of southern Russia, which include: Western China-Kazakhstan-AzerbaijanGeorgia-Turkey-EU; Western China-Kazakhstan-TurkmenistanIran; and Urumqi-Aktau-Baku-Poti-Port of Constanța, Burgas.

- North-South transport corridor, including the Eastern Route, Western Route, and the Central Trans-Caspian Route.

In terms of EU-China rail-based cargo transport, Belarusian-Polish crossborder is of special importance. Approximately $88 \%$ of all tonnage cargo passing through the Belarusian-Polish border goes westwards. Container freight is more balanced - the number of trains from China to the EU Member States is only $5 \%$ higher than the number of trains in the opposite direction. Almost $95 \%$ of the cargo flows pass through the Brest-MałaszewiczeTerespol cross-border point. If the container trains travel through the territory of the EAEU countries at high speed (at an average speed of 45 $\mathrm{km} / \mathrm{h}$ ), in Poland they slow down dramatically to $18-20 \mathrm{~km} / \mathrm{h}$. Due to regular delays at the Małaszewicze border crossing in 2017, logistics operators and forwarders began to look for alternative ways. As a consequence, in 2018, 59 trains (55 more trains than in 2017) crossed Bruzgi (Belarus)-Kuznitsa (Poland); two went to the crossing point Semyanivka-Svisloch (Grodno region), and 98 trains crossed the border with Poland through Kaliningrad, Russia (Shcherbanin, 2019).

On the other hand, it should be mentioned that Poland is now investing heavily in improving rail infrastructure especially on cross-border points, e.g., the modernization of the Terespol, Małaszewicze and Biala Podlask stations in 2020 (approximately 140 million US dollars); the Kobylian station expansion by 2023 (57 million US dollars); and the construction of a two-way bridge across the river Bug on the Terespol-Brest stretch (35 million US dollars). According to Polish experts, after completing the planned work, the border crossing capacity might increase up to 55 trains per day on both tracks (Shcherbanin, 2019). 
Figure 3. Rail directions of cargo transport through Belarus to the EU Member States in 2017

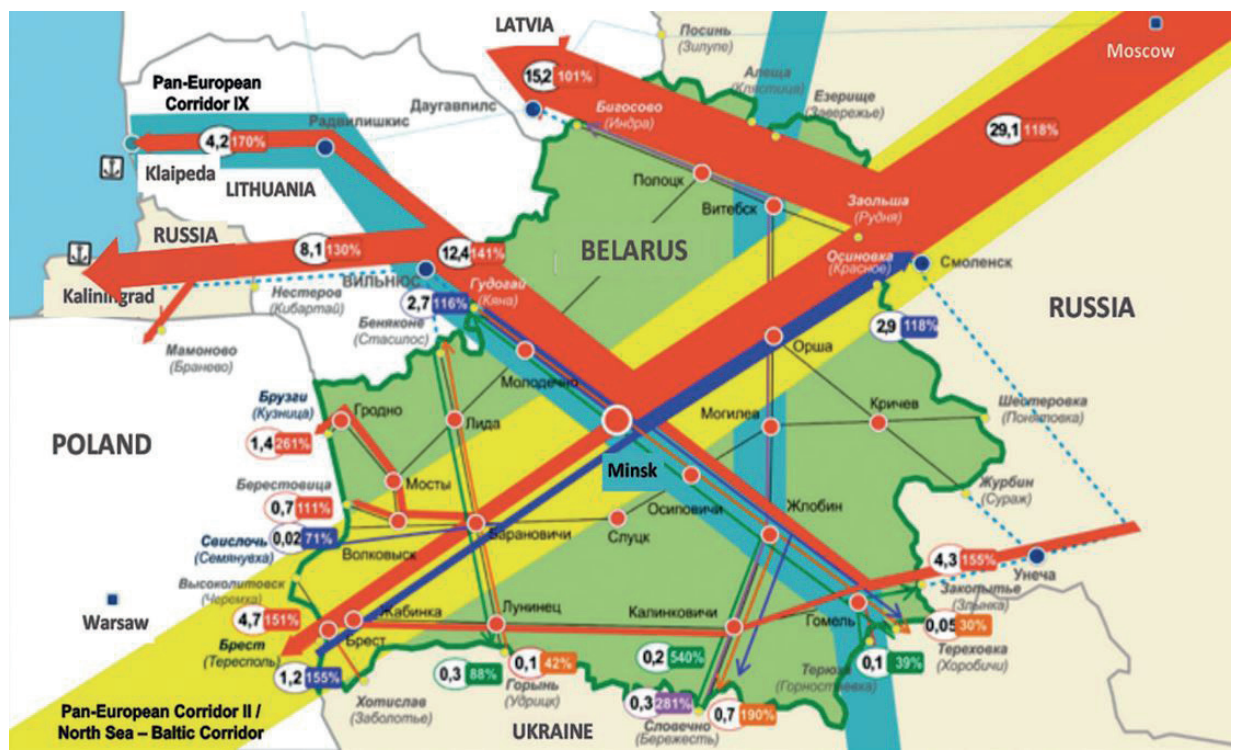

Source: Shcherbanin, 2019

A further challenge of OBOR may be the different standards of electrification network between Belarus and Poland and other EU Member States, which negatively influences the fluent transition of cargo on cross-border points. For example, in Poland, the voltage of contact rail network is $3 \mathrm{kV}$ of direct currency, and in the transit countries such as Kazakhstan, Russia or Belarus, the electrification network has a voltage of $25 \mathrm{kV} / \mathrm{AC}$ that allows transporting large-scale cargo trains (a hard factor based problem). Train's length regulation requirements were also named as the main barrier within land-based OBOR corridors between Western Europe and China. The train length fixed by different rail operators (e.g., Deutsche Bahn, Polish Railways, Russian Railways, the Belarusian Railway) depends on the length of the railway track at the station, train weight, traction capacity, route configuration profile, technical capabilities of stages of the railway (e.g., rail sidings and stations, overpasses and control posts, automatic blockages), shunting conditions at stations, technical and technological conditions at intermediate and local stations, sorting, etc. Transit operations within the OBOR corridor are also hindered by the difference in railway track gauges (e.g., 1,435 mm in China and the EU; 1,520 mm in Russia, Belarus and Kazakhstan). This results in additional expenses during cargo transport as wheel pairs need to be changed at border crossings, which is also time- 
consuming, especially for large cargo trains. The insufficient level of procedural harmonization was named as one of the important barriers to freight turnover along the OBOR land-based corridor. In most European countries, railway transport is regulated according to the Convention concerning International Carriage by Rail (COTIF). At the same time, railway administrations in the CIS countries, the Baltic States, Iran, China, and Mongolia are regulated by the Agreement on International Goods Transport by Rail (SMGS). The differences in the legal environment of transport also lead to insufficiently harmonized procedures at cross-border points. Also, clear customs and cross-border procedures are very time-consuming. In addition to the abovementioned problems, the interviewed experts noted that in the context of a high need of improvement of hard and soft based infrastructure, environmental issues within the OBOR corridor in China as well as in the transit countries are partly neglected or in the best case remain as a secondary factor.

\section{Rail Baltica}

The Rail Baltica project aims for the construction of a European railway link from Tallinn via Riga and Kaunas to Warsaw in order to connect the Baltic States to the European railway system. In 2017, the EU provided finances for the first investments and construction work and the company RB Rail AS is responsible for the coordination in the Baltic States. Usually, the Rail Baltica project is discussed in the context of green transport corridors (GTC) or growth corridors. However, recently, the discussions around the Rail Baltica project are held in the enlarged context of the New Silk Route. Some researchers have highlighted a tentative role for the Rail Baltica initiative in the context of the Northern Sea Route concept, i.e., maritime cargo transport between the Yellow Sea and Northern Europe via the Russian seaway. However, such an approach requires a connection between Estonia and Finland, such as the discussed Helsinki-Tallinn tunnel, which is still a plan for the future (Prause, 2019).

An important milestone in the development of the Rail Baltica concept dates back to 2010 when the EU approved the BSR Interreg project 'Rail Baltica Growth Corridor' under the lead of City of Helsinki 21 partners. Meanwhile, the Rail Baltica enjoys high priority within European TEN-T program to promote the multimodal integration and interoperability between the EU's 
North Sea and the Baltic TEN-T Core Network Corridor ensuring full integration of Estonia, Latvia and Lithuania into a single European railway area (Prause \& Hunke, 2014). The length of the railway between Tallinn and Warsaw will be at least $950 \mathrm{~km}$, and the first construction works started in 2018. The Tallinn-Riga-Kaunas standard-gauge route should be finished in 2026 with a connection to Warsaw in 2030.

The section between Helsinki and Tallinn is currently operated by ferries, and the future construction of the Helsinki-Tallinn tunnel is discussed to provide a rail link between the two cities. The whole planning process for the Rail Baltica was accompanied by ongoing discussions about ecological, financial and utilization issues that alleviated until the national elections in 2019 but have restarted in recent times (Tambur, 2018). The main issue of the discussions is the question of utilization of the Rail Baltica investments due to low population density and low north-south cargo streams in the Baltic States. Hence, the main issue concerns the justification of the high investment and operation costs, together with the ecological impact of railway constructions. Consequently, the supporters of the Rail Baltica initiative have to find additional arguments to ensure continuing political support for the project. The starting point of the Rail Baltica idea was mainly related to passenger traffic to offer a safe, environmentally friendly and fast link through the Baltic States with the possibility to connect to the Central European high-speed train network. However, this idea turned out to be unrealistic since the full distance of $1,500 \mathrm{~km}$ from Tallinn to Berlin was planned with a maximum speed of $120 \mathrm{~km} / \mathrm{h}$ and a total travel time of 15h. This is not any longer feasible, since after the start of the Rail Baltica project the maximum speed in the northern parts of Poland was reduced to $100 \mathrm{~km} / \mathrm{h}$ (Prause, 2019). The reduced speed of the final Rail Baltica will make the train use for passengers less attractive compared to a plane trip so that the estimated utilization of the train link might drop even further.

As a result, the Rail Baltica concept was modified towards a consideration of complementing rail cargo transport to increase the utilization rate. However, a closer look at the statistics shows that the largest part of the cargo volume inside the Baltic States is transported by truck and it alone is too small to fill the railway (Prause, 2019). Thus, additional rail transit traffic from Finland and Russia to Central Europe has to be taken under account for transportation. Both countries, Finland as well as Russia, have higher cargo transport volumes than the Baltic States but the cargo flows of both countries are mainly transported via truck or sea so that a potential utilization of Rail Baltica is linked with the need of a modal shift to rail. Hence, a prominent 
idea to open up the Rail Baltica for Finnish and Western Russian cargo to Central Europe is the development of Tallinn into a railway hub. This means strengthening of the Tallinn-St. Petersburg railway link and the construction of the Helsinki-Tallinn tunnel. Both measures are still in the planning phase, but the fantasy concerning the Helsinki-Tallinn tunnel grew with Finland's plans to establish the Arctic railroad from Rovaniemi to Kirkenes to link the Port of Kirkenes in Norway via a 1,400 km railway link with Helsinki. The existence of a tunnel between Tallinn and Helsinki would allow sending Chinese cargo via the Northern Sea Route around Russia, Kirkenes, the Arctic railroad, Helsinki and Tallinn and finally the Rail Baltica directly to Central Europe (Prause, 2019). Calculations reveal that the total travel time from Kirkenes to Berlin via the Arctic railroad and Rail Baltica sums up to $c a$. $32 \mathrm{~h}$. A comparison reveals the following total travel times between Shanghai and Hamburg (Prause, 2019):

- Shanghai - Hamburg via classical seaway:

28 days

- Shanghai - Hamburg via Northern seaway:

21 days

- Shanghai - Hamburg via Kirkenes \& railroads:

17.5 days

- Shanghai - Hamburg via Trans-Siberian railroad:

14 days

The above comparison points out that the multimodal cargo transport Shanghai-Hamburg via Northern Sea Route till Kirkenes and then using the Arctic railway and Rail Baltica represents a logistics solution that ranges in a comparable travel time like a Trans-Siberian transport. This short reflection highlights the already close relationship between the Rail Baltica and the OBOR projects, and since Russia is in all these considerations in the crossroads for the cargo transport, it is necessary to take the complementing initiatives into consideration.

An ambitious target of Rail Baltica is the New Silk Route interaction, which emerged with the start of the Russian Trans-Eurasian 'Meridian street' project. This infrastructural project tries to establish a land bridge between Kazakhstan via Moscow to Belarus to facilitate cargo transport all over Eurasia. The project comprises the strategic target to include the Kaliningrad region into all Eurasian transport corridors, i.e., the intersection of Rail Baltica and the Meridian project will be located in Lithuania, making Lithuania an outstanding strategic area for the interface between Eurasian transport corridors and, thus, for the development of logistics. Already now, Lithuania enjoys a prominent role in multimodal transport as one of the key areas for the East-West Transport Corridor (EWTC) linking the southern Baltic Sea and the Black Sea (Shcherbanin, 2018). The EWTC concept represents one of the most performant realizations of the green transport corridor concept of 
the European Union (Hunke \& Prause, 2013). Extensions of the GTC concept to all transport modes has been discussed already (Kusch et al., 2011) as well as the tentative role of GTC for economic growth and as a starting point for logistics service clusters. All these factors require high investment volumes and, according to the results of the investment survey, also here Lithuania enjoys all advantages due to its membership in the European Union, the foundation in the Eurozone and its stable frame conditions.

\section{Case studies, discussions and implications}

The study results, among other things, showed that cargo flow perspectives depend heavily also on the development of the European railway infrastructure, for example, cross-border points between Belarus and Poland, i.e., at the Brest-Małaszewicze border crossing, have been named as very limited. Moreover, the technical parameters of European railway infrastructure (i.e., the length of freight trains, types of platforms needed for the transport of containers, maximum allowed weight per axle, maximum allowed speed of freight trains) do not allow large container trains to be processed. While the length of freight trains in transit countries such as Russia, Kazakhstan and Belarus can reach 1,050 m, those cargo trains shall split into two parts with the maximum length of $600 \mathrm{~m}$ in length each at Małaszewicze in Poland. Accordingly, trains crossing the European border in Poland can have a maximum of 43 wagons carrying 86 TEU. As a result, if a normal 65-wagon container train from China via Belarus arrives at the Polish border, train wagons have to be split up: e.g., a 43-car train is composed as the containers are transshipped in Brest, while the remaining 22 cars have to wait at the marshalling station for the next train to be made up. This leads to high time and unit costs. Consequently, the BelarusPoland rail cross-border (e.g., Brest-Małaszewicze-Terespol) represents an important bottleneck so that some rail operators, including Russian Railways, redirect the westbound cargo traffic to Europe through other routes, especially through the Kaliningrad Oblast. According to experts' views, despite ongoing infrastructure improvements, those cross-border points will still remain bottlenecks in the near future.

Due to the current limited transit cross-border potential in some directions in Europe, increasing transit potential through the development of new routes, e.g., via Lithuania to Kaliningrad, may be considered (Beifert, 
Shcherbanin \& Vinokurov, 2018). In fact, in the framework of EWTC, joint efforts are being made focusing on the development of smooth, efficient and secure transport and logistics networks connecting China with Europe (via the Baltics). EWTC, among other things, promotes better connectivity of the Trans-European Transport Network (TEN-T) with the networks of the neighboring countries (here: Belarus, Russia and Ukraine) that at the same time belong to the main transit countries within the Eurasian land-based transport corridor. Thus, those initiatives may gain considerable attention, especially in the context of the possible integration opportunities of Rail Baltica and the OBOR transport corridors. In this context, a transport scheme of crossing the EU-CIS border has to be mentioned-the intermodal shuttle train VIKING, which has been operating since 2003 and has been developed within the EU funded project EWTC-II. The VIKING train moves from Klaipeda to Odesa ports via Minsk and Kyiv, the train departs 6 times per week and covers the distance of $1,734 \mathrm{~km}$ within 55 hours. In the context of EWTC, this train may also contribute to the sustainable connection of ports and hubs in the southern part of the Baltic Sea region, Karlshamn in Sweden, Klaipeda in Lithuania and Sassnitz port in Germany. Furthermore, there are practical plans to launch new container shuttle trains that might link Klaipeda and Kaliningrad ports, transport hubs in Moscow and Kazakhstan with China. Other cargo-shuttle trains associated with EWTC and Rail Baltica are in operation:

(1) The cargo/container train MERCURY, with a one-way distance of $1,342 \mathrm{~km}$, links the Klaipeda port with Moscow within 54 hours. This train has been in operation since 2011 and departs three times per week.

(2) The container train SAULE (Sun) operates on the so-called ad hoc basis. Linking itinerary Klaipeda hubs in Vilnius and Dostyk from Kazakhstan with Chongqing in China, it covers the distance of $10,929 \mathrm{~km}$ in 13 days. It has to be mentioned that "soft" challenges that enable to apply efficiently the same principles and regulations for improving crossborder procedures of cargo trains along the EWTC route were solved by signing an agreement by railway companies in Lithuania, Belarus and Ukraine. The favorable location of Lithuania on the intersection positions of Rail Baltica and the OBOR transport corridors as well as a EWTC hub provide a considerable competitive advantage for the cities of Vilnius and Kaunas in particular, which infrastructure may fully meet the market demands by establishing efficient links between transport hubs and terminals, enhancing transportation solutions not only within the EWTC, but also with Rail Baltica and OBOR. 
The ACC3 regulations, introduced in 2015, provide another opportunity for the perspectives of OBOR integration with Rail Baltica for Air Cargo or Mail Carrier operating into the Union from a Third Country Airport. Logistics hubs near the European border may be used as a pre-final receiving point to Europe of air cargo goods coming from non-certified airports-for example, to Grodno Airport in Belarus. Thus, for those air cargo destinations outside the EU without the ACC3 certification, Grodno Airport can be developed to a long-haul air cargo base due to its proximity to the European green transport corridors. A possible business model for Grodno Airport might be operational air cargo link to Europe from non-ACC3 certified destinations, whereas incoming and outgoing cargo is forwarded by normal truck or rail, for example, between Rail Baltica and EWTC and Grodno via the Belarus border (Beifert \& Prause, 2018; Beifert, Gerlitz \& Prause, 2018). This may offer a cost-efficient air cargo connection link between the EU and long-haul destinations that do not comply with the ACC3 regulations. Those plans require harmonization of policy regulations for the air-trucking services, which shall enable border-crossing procedures between the EU and Belarus as it is foreseen by the Road Feeder Services regulations, meaning that customs clearance for RFS-truck takes place in the respective customs area of the designated airports and not on road boarder crossing points (e.g., Belarus-Poland or Belarus-Lithuania).

Consequently, the Kaunas-Vilnius-Grodno triangle enjoys the perspective development towards a tri-modal logistics area, combining road, train and air transportation at the crossroads between north-south and east-west transport streams linking European corridors with OBOR projects. Hence, the already started cluster growth of logistics service in the KaunasVilnius range includes the option to be extended into the Grodno region. The mentioned challenges of soft and hard infrastructure can be further facilitated by the use of new technologies including the IoT, smart production and logistics as well as blockchain technology. The important consequence for the other two Baltic States might be that they can best participate from this development by further supporting Rail Baltica in their countries because, without this direct access to the Kaunas-Vilnius-Grodno area, the biggest parts of the logistics streams as well as the related economic growth potential might bypass the two countries. This threat is becoming a reality because Russia is already developing and promoting its own northsouth transport corridor. This new Russian North-South transport corridor (Buslovskaya-St. Petersburg-Moscow-Ryazan-Kochetovka-RtishchevoSaratov-Volgograd-Astrakhan) has a total distance of $2,513 \mathrm{~km}$ and is 
divided into three branches: Trans-Caspian: through the ports of Astrakhan, Olya, Makhachkala; Eastern: through the railway network of Kazakhstan, Uzbekistan and Turkmenistan with access to Iran at the Tedzhen-Sarakhs border crossing; and Western: Astrakhan-Makhachkala-Samur direction, Azerbaijan and access to Iran through Astara. The North-South Transport Corridor may also provide transport links between the Baltic countries and India through Iran. The main advantages of this corridor compared to other routes (e.g., seaway via the Suez Canal) consists in a reduction of distance and costs. However, one of the current problems of this North-South Transport Corridor is heavy traffic due to double cargo transhipment, which causes a considerable decrease in its competitiveness. In this regard, the creation of a direct railway line in the western direction of the transport corridor may be considered (Beifert, Shcherbanin \& Vinokurov, 2018). For this purpose, the construction of a new railway line linking with Iran, which, as the shortest route, may solve the transportation problem of goods between the ports of the Persian Gulf and the Baltic Sea and provide further cargo rail connection directly to India and Pakistan. Railway transport plays a key role in the formation of the entire integrated transport product of cargo delivery through an international transport corridor, and it might be necessary to ensure integrating a balanced development of some links of the entire chain of international transport, for example, by including the management of the largest seaports, land terminals of the organization of railway transport (Beifert, Shcherbanin \& Vinokurov, 2018). This is to ensure a balanced and effective pricing policy and to make all action for planning and dispatching the transportation process consistent.

\section{Conclusions}

The fast growth of Europe-China container traffic provides huge opportunities for the further development of an alternative to traditional sea mode routes. In this context, land-based Eurasian transport corridors gain special attention and importance. China's investments in the framework of the OBOR initiative are seen by stakeholders from the EU and from transit countries both as an opportunity (economic growth perspectives) and as a threat due to indirect subsidies of the Chinese government for cargo flows of a Chinese origin that may negatively influence the development of local economic structures in the transit countries such as Russia, Kazakhstan and Belarus. On the other hand, despite the strong political interest in Rail 
Baltica, a critical mass of potential investors, especially from Europe, is still missing. Compared to the OBOR initiative with real Chinese investments and functional operational capacities, at the moment the Rail Baltica initiative may hardly be viewed as a project having the required financial resources to start real infrastructural investments as well as functional operability. Potential investors of Rail Baltica are also hesitant due to lack of information, or example, on technical data concerning its railway maintenance costs, including transparent evaluation of maintenance cost of two different rail systems, evaluation of cargo and passenger capacities, utilization rate, etc. Moreover, the current situation of COVID-19 has had a negative effect both on transported volumes as well as on the investment climate.

On the other hand, Rail Baltica benefits from a number of advantages such as efficient concepts like the green transport corridor, transparent tariff policy, the stability of relevant national institutions in transit areas, etc. Thus, to make the OBOR project more viable and attractive also for potential investors from Europe, along with improving such global issues as the stability of institutions in China or the transparent transport tariff policy in the transit countries, integrative opportunities with EU supported projects like Rail Baltica or East-West Transport Corridor may be considered. Since the Belarus-Poland rail cross-border (e.g., Brest-Małaszewicze-Terespol) represents a bottleneck in the context of the OBOR initiative, some rail operators (e.g., Russian Railways) redirect westbound cargo flows to Europe through other routes, for example, via the Kaliningrad oblast. Thus, an opportunity for Rail Baltica may be in this context to catch "redirected" cargo flows, new "hotspot logistics areas" such as developing the KaunasVilnius-Grodno triangle linking the EU and OBOR.

Furthermore, the integration and close collaboration of OBOR and Rail Baltica might improve the interoperability of logistics centres, involve relative stakeholders as well as promote the environmentally friendly concept of green transport corridors and development of sustainable logistics clusters along the Eurasian transport routes via the Baltics. Such new technologies as the IoT, Industry 4.0, blockchain, smart contracts that are already being tested and implemented in Rail Baltica facilitate supply chain communication, entrepreneurial cooperation, enhance efficiency and reduce transaction costs. Since economic growth potential along the transport corridors is of high importance for the participating regions, by improving transparency and trust that is partly missing in the OBOR projects those integration components may boost entrepreneurial activities and general 
economic growth in all areas of proximity. Finally, in a long-term perspective, the integration of OBOR and Rail Baltica may provide a unique opportunity of a joint improvement of soft-based infrastructure such as regulations and requirements in participating regions.

Anatoli Beifert is the head of the EU Programme 'MOST', and works as an associate professor in Wismar University of Applied Sciences, Germany. His research focus is on transport and logistics, shipbuilding sector and regional development.

Gunnar Prause is a professor at the School of Business Administration and Governance of Tallinn University of Technology in Estonia and Wismar Business School in Germany. He is the board member of the Institute of Cooperative Studies at Humboldt University Berlin and he enjoys a long experience in national and European projects. His research focus is business development, innovation and sustainable supply chain management.

Yuri Shcherbanin is director of the Centre for Integration Studies, Eurasian Development Bank, and a professor of the Russian Academy of Sciences. His research focus is on transport and logistics, especially rail-based transport corridors.

\section{References}

Beifert, A.; Gerlitz, L. \& Prause, G. (2018), 'Industry 4.0 - for sustainable development of lean manufacturing companies in the shipbuilding sector,' Springer Lecture Notes in Networks and Systems, vol. 36, pp. 563-573. https://doi.org/10.1007/978-3-319-74454-4_54

Beifert, A. \& Prause, G. (2018), 'Integrating air cargo road feeder services into green transport corridors,' Springer Lecture Notes in Networks and Systems, vol. 68, pp. 409-420. https://doi.org/ 10.1007/978-3-030-12450-2_38

Beifert, A.; Shcherbanin, Y. \& Vinokurov, E. (2018), Trans-Eurasian Land Transport Corridors: Assessment of Prospects and Barriers, IIASA Report, Laxenburg, Austria.

BSR Transport Cluster (2012), Transport Research Project in the Framework of the INTERREG IVB Programme. Retrieved from http://transportcluster.eu [accessed Oct 2020] 
European Transport Policy for 2010: Time to Decide, White Paper, Commission of the European Communities, COM (2001) 370 final, 12.9.2001.

Hunke, K. \& Prause, G. (2013), 'Management of green corridor performance,' Transport and Telecommunication, vol. 14, no. 4, pp. 292-299.

https://doi.org/10.2478/ttj-2013-0025

Kusch, T.; Prause, G. \& Hunke, K. (2011), 'The East-West Transport Corridor and the shuttle train 'VIKING', Wismarer Diskussionspapiere, no. 13.

Lee, P. (2005), 'Measuring supply chain integration: a social network approach,' Supply Chain Forum: An International Journal, vol. 6, no. 2, pp. 58-67. https://doi.org/10.1080/16258312.2005.11517148

Philipp, R.; Prause, G. \& Gerlitz, L. (2019), 'Blockchain and smart contracts for entrepreneurial collaboration in maritime supply chains,' Transport and Telecommunication Journal, vol. 20, no. 4, pp. 365-378.

https://doi.org/10.2478/ttj-2019-0030

Pieriegud, J. (2019), Development of Rail Container Transport Market in Poland, Final Report. Contract No. 2018CE 16BAT079, Directorate-General for Regional and Urban Policy, Brussels: European Commission.

Prause, G. (2014a), 'A green corridor balanced scorecard,' Transport and Telecommunication, vol. 15, no. 4, pp. 299-307.

https://doi.org/10.2478/ttj-2014-0026

Prause, G. (2014b), 'Sustainable development of logistics clusters in green transport corridors,' Journal of Security and Sustainability Issues, vol. 4, no. 1, pp. 59-68. https://doi.org/10.9770/jssi.2014.4.1(5)

Prause, G. (2019), 'The Rail Baltica and the New Silk Route: new corridors for Eurasian supply chains,' in M. Schröder \& K. Wegner (eds.) Logistik im Wandel der Zeit: Von der Produktionssteuerung zu vernetzten Supply Chains, Wiesbaden: Springer, pp. 103-120. https://doi.org/10.1007/978-3-658-25412-4

Prause, G. \& Hoffmann, T. (2017), 'Cooperative business structures for green transport corridors,' Baltic Journal of European Studies, vol. 7, no. 2(23), pp. 3-27. https://doi.org/10.1515/bjes-2017-0008

Prause, G. \& Hunke, K. (2014), 'Sustainable entrepreneurship along green corridors,' Journal of Entrepreneurship and Sustainability Issues, vol. 1, no. 3, pp. 124-133. https://doi.org/10.9770/jesi.2014.1.3(1)

Prause, G.; Mendez, M. \& Garcia-Agreda, S. (2013), 'Attitudinal loyalty and trust in entrepreneurship: building new relationships,' International Entrepreneurship and Management Journal, vol. 9, no. 4, pp. 531-540. https://doi.org/10.1007/s11365-011-0215-y

Roadmap to a Single European Transport Area - Towards a Competitive and Resource Efficient Transport System, White Paper, Commission of European Communities, COM(2011) 0144 final, 28.3.2011. 
Sarkis, J. (2001), 'Introduction,' Greener Management International, vol. 35, no. 3, pp. 21-25. https://doi.org/10.9774/GLEAF.978-1-909493-22-3_2

Schröder, M. \& Prause, G. (2015), 'Risk management for green transport corridors,' Journal of Security and Sustainability Issues, vol. 5, no. 2, pp. 229-239. https://doi.org/10.9770/jssi.2015.5.2(8)

Shcherbanin, Y. (2018), 'Mezhdunarodnyi transportnyi koridor "Sever-Iug": shto poluchilos', Transport Rossiiskoi Federatsii, no. 6(79), pp. 3-6.

Shcherbanin, Y. (2019), 'Initsiativa poiasa i puti: Pol'sha, tranzit, vykhod na evropeiskie puti i politika,' Transport Rossiiskoi Federatsii, no. 3(82), pp. 3-10.

Sheffi, Y. (2012), Logistics Clusters - Delivering Value and Driving Growth, Cambridge, MA: MIT Press.

Tambur, S. (2018), 'The Rail Baltica project should be suspended until all questions are answered,' Estonian World, 11 April. 